\title{
ACTIVITY OF LACTATE DEHYDROGENASE IN THE COURSE OF EXPERIMENTAL TRICHINELLOSIS IN GUINEA PIGS
}

\author{
B. KOUDELA, H. SCHANZEL
}

Department of Pathological Morphology and Parasitology, University of Veterinary Science, 61242 Brno

Received fuly 7, 1979

\begin{abstract}
Koudela B., H. Schanzel: Activity of Lactate Dehydrogenase in the Course of Experimental Trichinellosis in Guinea Pigs. Acta vet. Brno, 49, 1980: 85-89.

Activity of the total plasma LDH has been determined in the course of trichinellosis in experimentally infected guinea pigs. Blood samples were processed by a modified micromethod using the SEVATEST LDH outfit. Enzymatic activity was determined and limits of confidence were calculated to evaluate results.

In uninfested guinea pigs, the mean value for total LDH activity was $164.02 \pm$ $\pm 39.84 \mathrm{IU} / \mathrm{L}$. Differences were observed in connection with age and sex. Following infestation by Trichinella larvae, the $\mathrm{LDH}$ activity increased gradually till 6 th week, reaching so its peak when the period of migration was completed and the larvae definitely settled in muscles.
\end{abstract}

Lactate dehydrogenase, trichinellosis.

A number of interactions have been described between host and Trichinella larvae. Apart from changes in the quantity of total nitrogen, creatine, purine bases, water, lactic acid, volatile fatty acids, ammonia and different products of muscle decay, some alterations in enzymatic reactions have been observed. Malik et al. (1960) described increased activity of transaminases (GOT, GPT) and aldolase, Schanzel and Holman (1966) increased activity of phosphatases, while no changes in the activity of creatine phosphokinase were reported in experimentally infested guinea pigs (Schanzel and Koudela 1978).

The present experiment reports on the activity of lactate dehydrogenase in the course of trichinellosis in guinea pigs. LDH manifests no specificity to particular organs. The enzyme is ubiquitous in the organism, its content in liver, heart and skeletal muscles being, however, predominant. Deviations in LDH activity result from physiological muscle strain as well as from pathological processes such as various muscular dystrophies and tumors (Haschen 1970; Gschwender 1969). For their diagnosis, analysing the proportion of different isoenzymes is more conclusive than determining total enzymatic activity.

The present preliminary experiment has been carried out in order to study the dynamics of alterations in total LDH activity, if any, consequent to experimentally induced trichinellosis in guinea pigs. Since no data were available concerning physiological LDH activity in guinea pigs, we first had to determine them in guinea pigs of different sex and age.

\section{Materials and Methods}

\section{Physiological LDH values}

Total plasma LDH activity was determined in 29 guinea pigs (12 males, 17 females) of 440 to $930 \mathrm{~g}$ body mass. Heart punctures were carried out in narcotised animals to collect blood samples into heparinised test tubes. The samples were centrifuged immediately, plasma transferred into Eppendorf microtubes and storred in a freezing box. Haemolyzed samples were excluded. A modi- 
fied micromethod was employed to process plasma samples, using the SEVATEST LDH set. Measurements were performed on a Eppendorf spectrophotometer at $492 \mathrm{~nm}$ wave length. In groups of guinea pigs the effect of age and sex on the activity of LDH were evaluated. Limits of confidence were calculated for statistical evaluation.

Total LDH activity during experimental trichinellosis

A total of 70 female guinea pigs of $180-500 \mathrm{~g} \mathrm{~b}$. m. were infested by approximately $1,000 \mathrm{Tr}$ chinella larvae each. Blood samples were collected succesively from 10 animals each week. The samples were processed as described for physiological values. After collecting blood samples, the animals were killed. One gram of diaphragma muscles were removed from each guinea pig, and, the Trichinella larvae present counted to obtain the criterion for the intensity of infestation.

\section{Results}

Fig. 1 shows the physiological values for total plasma LDH activity in guinea pigs. The mean value was $164.02+39.84 \mathrm{IU} / \mathrm{L}$. It is obvious that the enzymatic activity in males $(175.27 \pm 69.07 \mathrm{IU} / \mathrm{L})$ was significantly higher than in females $(156.32 \pm 53.64 \mathrm{IU} / \mathrm{L})$.

From Fig. 2. it can be seen that the LDH activity increased with body mass (age) to a certain level and then decreased slightly.

The results of the trial with infested guinea pigs are demonstrated in Fig. 3. There was an obvious trend of significantly increasing $\mathrm{LDH}$ activity till 6th week after infestation.

Fig. 4. illustrates the correlation between LDH activity and intensity of infestation by Trichinella larvae.

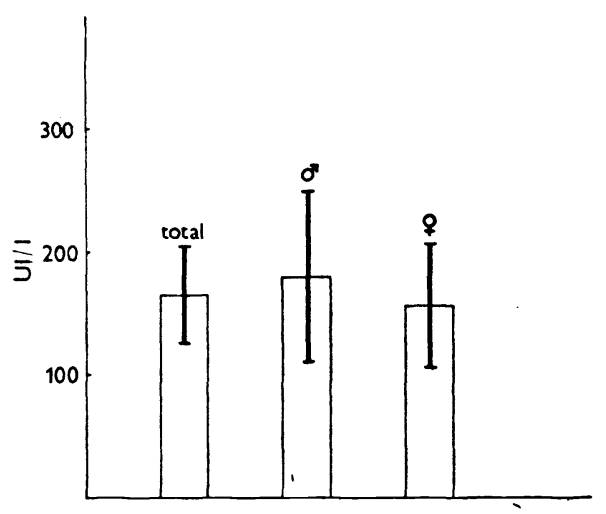

Fig. 1.

Physiological values of $\mathrm{LDH}$ activity in guinea pigs.

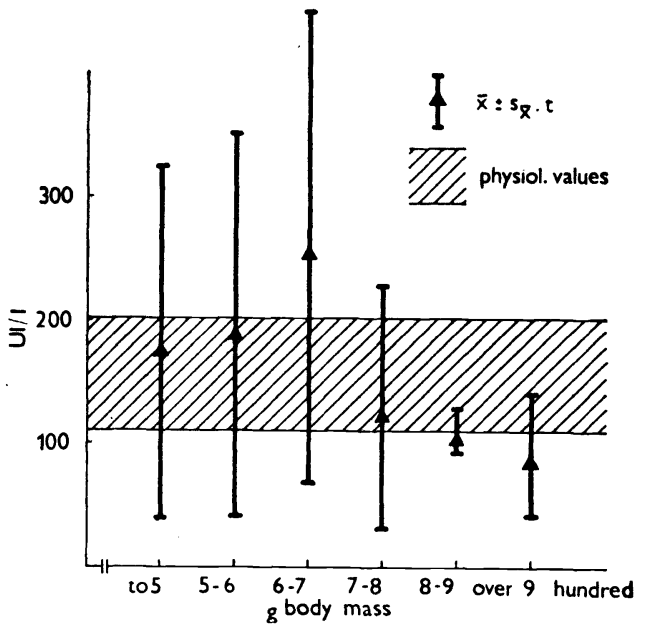

Fig. 2.

Correlation between LDH activity and body mass in guinea pigs.

\section{Discussion}

No comparable date were found in literature concerning physiological values for total plasma LDH activity in guinea pigs. As for the fact that in male animals significantly higher values were recorded than in females, similar differences were reported with other enzymes, for example with creatine phosphokinase. 
The total LDH activity increased up to $600-700 \mathrm{~g} \mathrm{~b}$. m. of guinea pigs, and then decreased slowly in relation to the growing body mass of the animals. An explication might be that this increase is due rather to muscle mass increment during the earlier period and to fat tissue increment following later, and also to the fact that young animals exert more motor activity.

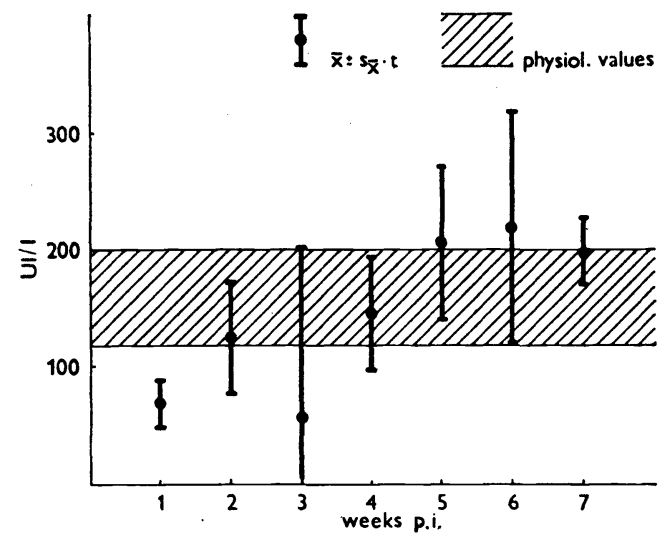

Fig. 3.

Activity of $\mathrm{LDH}$ in guinea pigs infested by Trichinella spiralis larvae.

In guinea pigs infested by Trichinella larvae, the total plasma LDH activity increased continuously until the 6th week $p$. i. The break of this trend, seen at 3rd week in Fig. 3., was consequent to haemolysis of several samples, so that only two samples were left for measurements.

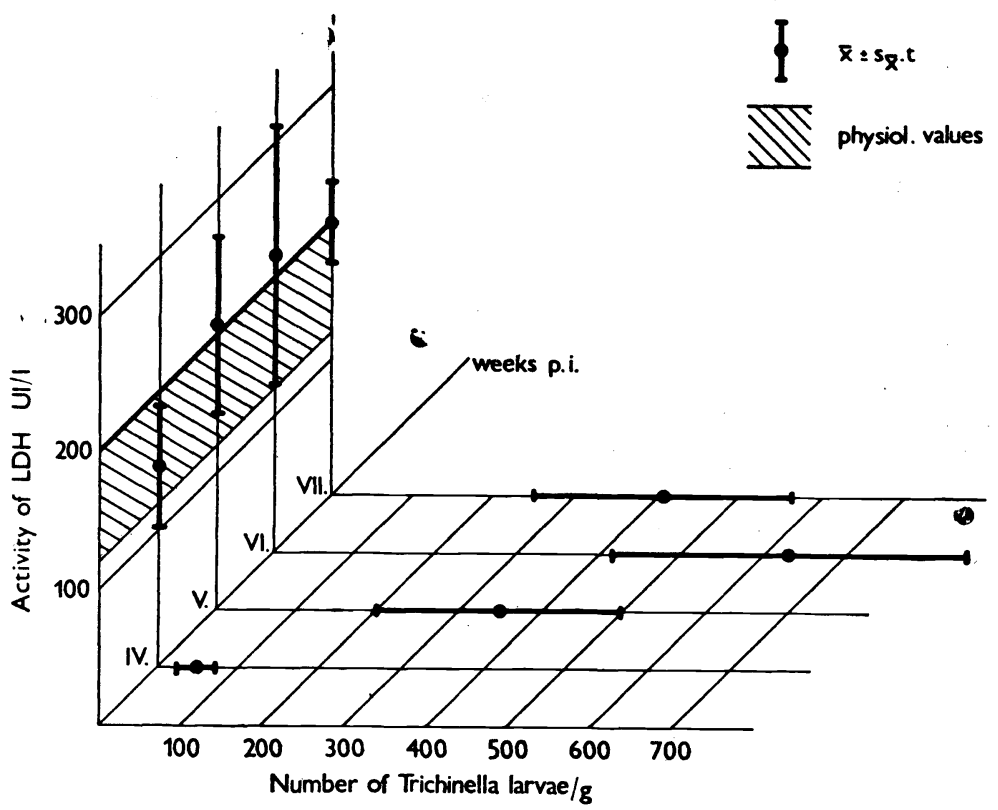

Fig. 4.

$\mathrm{LDH}$ activity and number of Trichinella spiralis larvae per gram of muscle tissue in guinea pigs. 
LDH activity significantly exceeding physiological values observed in our uninfested group was registered at the age of 5 and 6 weeks, implying that the alteration in enzymatic activity was connected with the phase of larval migration only. The continuous increase in LDH activity was correlated with the successively growing number of muscle larvae, as it is illustrated in Fig. 4.

The correlation between enzymatic activity and intensity of infestation was not always obvious when comparing different guinea pigs within one group. A high LDH activity for example was determined in one animal which had 71 larvae/g muscle tissue at 5 th week p. i., while a low enzymatic activity was found in a guinea pig with as much as 1,585 larvae/g. It is probable that the increase of enzymatic activity was of short duration similarly as described with hepatitis and myocardial infarction by Wörner (1966) and Gschwender (1969). Consequently, measurements performed in weekly intervals might actually register increased LDH values caused by a portion of the larvae and not yet or not more by the rest of them.

Provided confirmation of our results by similar trials with more animal species, it will be doubtlessly expedient to carry out an analysis of isoenzymes involved in the course of trichinellosis. Alteration in activity of specific isoenzymes should be more explicit, and if so, such analyses might serve as supporting tests for intravital diagnosis of trichinellosis.

\section{Aktivita laktátdehydrogenázy $v$ průběhu experimentální trichinelózy morčat}

U experimentálně vyvolané trichinelózy morčat jsme sledovali enzymatickou aktivitu celkové plazmatické laktátdehydrogenázy. Postupně odebírané vzorky krve se zpracovávaly modifikovanou mikrometodou se SEVATESTEM LDH. Pro statistické vyhodnocení se vypočítaly meze spolehlivosti.

U neinvadovaných morčat se zjistila průměrná hodnota enzymatické aktivity celkové LDH $164,02 \pm 39,84 \mathrm{IU} / \mathrm{L}$. Odchylky souvisely s věkem a s pohlavím zvírat. Po invazi aktivita LDH plynule vzrůstala do 6 . týdne po infekci, takže dosáhla vrcholu $\mathrm{v}$ době, kdy končilo období larvální migrace a larvy se definitivně usadily ve svalovině.

\section{Активность лактатдегидрогеназы при экспериментальном трихинеллезе}

У 29 морских свинок было установлено, что общая активность плазматической лактатдегидрогеназы у морских свинок составляет $164,02 \pm 39,84$. Уровень этой активности варьирует в зависимости от возраста и пола морских свинок.

Общая активность плазматической лактатдегидрогеназы после инвазии личинками рода Trichinella равномерно повышается вплоть до 6-ой недели после заражения, достигая вершины во времени, когда личинки окан чивают свою миграцию и дефинитивно поселяются в мышечном волокне.

\section{References}

GSCHWENDER, B.: LDH-Isoenzyme und ihre Bedeutung für Diagnostik und Verlaufsbeurteilung verschiedener innerer Erkrankungen. Thesis München, 1969.

HASCHEN, J. R.: Enzymdiagnostik. G. Fischer, Jena, 1970.

HOLMAN, J. - SCHANZEL, H.: Histochemie der saueren Phosphatase in der Muskulatur 
von mit Trichinella spiralis experimentell angesteckten Meerschweinchen. Sborník VŠZ, B, 35, 1966: 73-78.

MALIK, A. - NIEWIOROWSKI, S. - RACHOŃ, K.: (In: Kozar, Z.: Trichonellosis, PWN, Warszawa, 1962: 219-224.

PFLEIDERER, G. - JECKEL, D.: Individuelle LDH bei verschiedenen Säugetieren. Bioch. Z., 329, 1957: 370-380.

SCHANZEL, H. - HOLMAN, J.: Lokalisation der alkalischen Phosphatase in der trichilnellbefallenen Muskulatur. Angew. Parasit., 4, 1966: 252-259.

SCHANZEL, H. - KOUDELA, B.: Activity of creatine phosphokinase in the course of experimental trichinellosis. Acta vet. Brno, 47, 1978: 91-95. 